http://dx.doi.org/10.12775/szhf.2015.052

Maria Abysova

National Aviation University, Kiev, Ukraine

NORA_@BIGMIR.NET

\title{
S. Krymskyi: Philosopher of Transitional Period
}

The history of philosophy of the late Soviet period now confidently wins the status of an essential branch of historico-philosophical studies. Considerable originality distinguishes this branch from the others. Among its notable features there is the fact of extremely rapid changes in the nature of philosophical discourse which bears for the modern generation of humanitarians the acute problems of high intellectuals of this recent time. The study of the heritage of S. Krymskyi gives the possibility to clarify some vague sides of philosophical life of that period.

The choice of Serhii Krymskyi is not accidental. He was more than a profound scholar due to his extremely bright, distinctive personality possessing the inexhaustible reserves of philosophical reflection, which does not lose its lustre even in ordinary situations. Besides, the very creative road of S. Krymskyi makes his biography perhaps the ideal mediator in communication of modern readers interested in philosophy with 'that time'.

S. Krymskyi once described himself as a philosopher of the transition period. It is thought that this characteristic is true not only in relation to the evolution of philosophical views which S. Krymskyi passed from his passion 
of G. Hegel to mathematical logic and from mathematical logic to the philosophy of culture and religion. Being one of the most prominent Kyiv philosophers in Soviet times, S. Krymskyi has become a cult thinker, a symbol of philosophizing itself for many in post-Soviet Ukraine.

Joining of S. Krymskyi to the brotherhood of Kyiv philosophers of postwar training, which was turning out into the backbone of the Institute of Philosophy of Academy of Science of the USSR and laying the traditions that determined the nature of Kyiv philosophical community for decades, coincided with the Communist harassment at humanities innovations as dangerous ones for the existing regime. In order to escape the fight for Marxism-Leninism 'purity' in social sciences prominent Soviet philosophers (P. Kopnin, I. Golovakha, S. Krymskyi, M. Zlotina, and others) preferred to choose the themes of logic, logic and methodology of scientific cognition, and philosophical questions of natural sciences.

Researches on current problems of logic, methodology and philosophy of science have turned into a powerful academic movement since 1962, due to the efforts of a newly elected head of the Institute of Philosophy - P. Kopnin. The result of the work was a significant monograph "Logic of Scientific Research" (1965) written by P. Kopnin, S. Krymskyi and M. Popovich. With the help of conceptual tools of formal logic and methodological potential of dialectics (not vulgar one but elaborated by representatives of German Classical Philosophical Tradition), the monograph reconstructs the scientific research as a logical sequential process; it traces the movement of a cognitive act from genesis and formation of empirical, factual base through various degrees of abstraction to higher levels of synthesis and structuring of knowledge - scientific systems, scientific theories, and scientific worldview.

Being true to his heuristic credo, S. Krymskyi focuses his attention on one of the fundamental aspects of substantive content of scientific theories, i.e. the relationship of theory and empirism, the theoretical and the empirical. He keeps track of scientific research from the formation and synthesis of empirical framework to the emergence and substantiation of a scientific theory, and then in the opposite direction - the transition from theory to empirism, identical with the process of filling the abstract theoretical structures with substantive content. It requires a special logical procedure, which is opposite to abstraction in its direction. From the author's point of view the required procedure is an interpretation of a theoretical system. S. Krymskyi defines the essence of interpretation, reveals its conceptual framework, clarifies its heuristic role, and describes its different types. The scientific value 
of the research implies the first attempt to analyse the interpretation of scientific theories as a logical operation.

The appeal to formalize methods of scientific theories, a wide use of deductive schemes in science and an interpretation operation connected with them, and the phenomenon of the multiplicity of models of subject presentation of abstract theoretical structures revealed for S. Krymskyi new logical methodological problems, i.e. mutual transfer of settled scientific theories, and transition of the old system into a new one.

The object of S. Krymskyi's study in the monographs "Logic of Scientific Research" and "Scientific Knowledge and its Transformation Principles" (1974) is, on the one hand, logical principles of transformation of scientific theories and, on the other, the logical principles of theoretical genesis. Analysing the ways of arranging of theoretical systems the author dealt with heuristic functions of the main form-making factors of theory - application, the method of 'floating' form, algorithm, and the principle of duality. He formulated the principle of the transfer of deductive schemes or transformation groups of the original theory on a new theoretical system by means of transportation of certain objects. Summarizing the so-called principle of impossibility and principle of limitedness, S. Krymskyi justified a ban principle on certain situations of creating a new theory, which allows defining the scope of the impossible and eliminating the paradoxes of the old theory. To resolve the contradictions that occur in the theoretical system and to achieve the completeness of the latter, the author proposed to rely on the principle of accession of ideal elements to the original theory axioms, which allows expanding the domain of a new theory at the expense of ideal or virtual objects coincided with empirical objects in the process of verification of the theory. Heuristic functions of permanence and compliance principles are formulated and demonstrated with the help of examples taken from mathematical and physical theories.

In the monographs "Rationality in Science and Culture" (1989) and "Request of Philosophical Meanings" (2003) S. Krymskyi put forward and substantiated an original concept, which states that rationality is not an abstract phenomenon. The origins of rationality are rooted in the forms and methods of man's practical mastering of reality, connected with the type of man's worldview and definite type of scientific knowledge and culture. Rationality is a phenomenon that penetrates all the forms of man's life; it is associated with the power of the human mind and its ability to arrange the process of life properly, to be a tool of motivated choices, solutions, opportunities, or 
actions. The philosopher developed the theory of rationality, its conceptual structure, and a typology of rationality. S. Krymskyi's interpretations of the method as embodied rationality, whatever fields (science, art, and practice) it is connected with, his presentation of practical rationality in the form of technological expediency, and his allocation of a separate type and characteristics of the art rationality (an artistic method as its vivid exponent) are very innovative.

In the history of humanity the rational is inseparable from the irrational, the conscious from the unconscious, the controlled from the spontaneous, the constructive from the destructive and so one. Therefore, considering man's life, his multifaceted activity, the author focused his attention on problematic situations in which they occur. The solution of any problematic situation is associated with balanced, optimal and reasonable solutions serving as a guide to achieve desirable results. In this meaning solutions can be qualified as productive ones if the subject making a decision is founded on the scientifically proven basis and socio-historical experience accumulated by the relevant system of rational principles.

In this context S. B. Krymskyi formulated and proved the following principles of rationality: a) measure-determination according to which the rational is in some range, determined by the laws of symmetry and norms opposed to permissiveness; b) well-ordered sequences, which requires to comprehend the phenomenon of the problematic situation in the context of a number of logically lined up actions, ensuring their predictability, algorithm, validity; c) relief of binary oppositions, linking rational reasoning and actions with clear separation of truth from falsehood, right from wrong, real from illusory, subjective from objective, meaningful from meaningless, good from evil, justice from injustice, etc; d) analyticity that involves consideration of any object as a combination of simple elements and the possibility of their recombination by moving from simple to complex; e) epistemological doubt (irony) opposed to the dogmatic mind, uncontrolled absolute spirit and ideology of eternal truths; f) ethical value of truth, which establishes the priority of any truth, even threatening one in contrast to a sweet or selfish lie; other principles. The concept of principles of rationality was repeatedly examined by S. Krymskyi in his later work: "Philosophy as a Way of Humanity and Hope" (2000).

Scientific heritage of S. Krymskyi was not limited with themes of logic and methodology of science. His inquisitive mind constantly invaded other philosophical disciplines to overcome the challenges existing there. At first, 
his scientific interest for other areas of philosophical reflection played a subordinate role; it was a testing ground for logical and methodological ideas. However, it gradually became more and more important for him and subsequently transformed into separate areas of his scientific work, which can be called culturological and socio-humanitarian ones.

Kyiv philosophy tradition in the Soviet period in its worldview issues, manoriented interests developed by P. Kopnyn, S. Krymskyi, V. Shynkaruk, V. Tabachkovskyi, and many others became a legitimate successor to the Ukrainian tradition of philosophizing, that is humanism of T. Shevchenko, I. Franko and L. Ukrainka, philosophy of heart of P. Yurkevich, and the concept of microcosm and macrocosm developed by G. Skovoroda.

Culturological direction in the work of S. Krymskyi was developed through the deployment of two different although related trends-epistemological issues in the context of philosophy of culture, and philosophy of Ukrainian national culture. Both subjects were synthesized later on in the studies of philosophy of spirituality.

In the first case S. Krymskyi exposed the phenomenon of culture in different ways: its rational basis, chronotope and symbolic manner, the interaction of science and culture, the phenomenon of science in culture and cultural factors in the world of science, forms of cultural and historical mediation of scientific knowledge.

In the thorough work "Epistemology of Culture" (1993), forms of movement of knowledge in the context of culture are analysed. Culture is understood by the philosopher as "a system of transferring of values of the present in man's being, escaping into the past and dissolving into the future. This is the method of constructing of man's life at the expense of the experience of hundreds of past generations, due to realized and - most important - unrealized potentials of historical activity." And further: "Culture can be defined as the reproduction of human history in its potentiality and the free development of man's essential strengths"'. A form of combination of personality and history in the culture is called a "style" most fully and adequately revealed in the symbolic order. The symbolism is "not only the language of culture but also the condition of man's life and consciousness. In this perspective, culture is a sphere of objectifying and disobjectifying of symbolic experience of the

${ }^{1}$ S. Krymskyi, B. Parakhonskyi, V. Meizerskyi, Epistemology of Culture: Introduction to Generalized Theory of Cognition, Kyiv 1993, p. 32. 
mankind"2. Thus the culture is associated with symbolization of things and events in which the sense and value potential of objects of the human world are revealed.

In this respect, the world of culture is sophiological and its objects are informationally loaded, similar to semantic functions of sign systems. Thus, in a culture the gap between being and value, fact and meaning is overcome. "The reality appears as the embodied rationality of the highest ideals and values of many generations of people"3.

The book contains the prototype of principles of 'ethical virtues of truth', concept of world of symbols as a 'third reality' between the 'microcosm' of man and the 'macrocosm' of the universe deeply developed by the philosopher in his further researches. Thus, the work represents a consistent philosophy of culture, despite its compressed form.

There is another profound idea elaborated by the philosopher, i.e. the concept of invariants of culture. He claims that any significant step into future in every culture is possible only to the extent of mastering of the past and its potentialities, empowering the cultural potential of progress. The idea of the existence of core, central and axiologically significant cultural and historical forms defining at the high, metahistorical, 'time link' level is represented. Time link here is an indicator of imperishable cultural values ${ }^{4}$. Among those, in particular, he calls Good, Truth and Beauty.

Krymskyi writes that the most modern ideas of science, as a rule, have preimages (or rather, analogues in the form of fantastic anticipations or conjectures) in the history of culture. And, the more significant an idea is the bigger number of its cultural analogues or pre-images in the past could be found. The most important of them, such as the idea of atomism and evolutionism, conservation of matter and movement, symmetry and harmony, ether and continuity and others, have been permeating the entire history of civilization, marking mythological, philosophical speculations, artistic insights and rigorous scientific facts and principles of modern scientific picture of the world.

Here we see the problem of access to the common cultural archetypes as the basic structural components of culture. Archetypes, according to Krymskyi, "as symbolic constructions, are decrypted through interpretation in different figurative representations." Cultural archetypes are related to Jungian

2 Tamże, p. 33.

3 Tamże, p. 35.

${ }^{4}$ Tamże, p. 38-39. 
archetypes of the collective unconscious, but not reducible to them and are not displayed: "Archetypes only show a predisposition for the future knowledge $[\ldots]$ ". . The ability of such unique universal symbols to be a basis for substantive interpretations shows the possibility of knowledge preceding cognition. S. Krymskyi went on examining the cultural-historical models of cognition. He found out that the models of cognition correspond to specific forms of culture, "and therefore it is a possible historical, temporal link to certain periods of the world history"6. He identifies five cultural-historical models of cognition within the Mediterranean-European macro-region since Antiquity till nowadays.

System analysis of civilization definitions of culture from logical-methodological positions initiated by S. Krymskyi ("Civilizational Models of Modernity" (2002), "Under the Signature of Sofia" (2008) and "Morning Reflections" (2009)) leads to a truly innovative concept of personality. Personality is the personification of the world process. The latter is defined as "the formation of a man in his cosmic assumptions, anthropogenesis and further self-creation as a main line of the world history." The result of this process is "the assertion of the monadic person capable for representing the whole world in the form of sense-valued Universe of the mankind, its culture and socio-ethnic accomplishments" . In this context, man embodies "a high degree of individualization of essence," he represents the type of existence unlike the being of things. Man's being "turns into existence, including the attitude to the self as to the dedicated specified ego. [...] Sensation of the depth of self-existence embodies the phenomenon of man's ego, his personality"8.

The most important mean of self-creation, discovery of the self as a personality, is culture, defined by S. Krymskyi as man's world. "As a world of historical experience and human activity, culture at the same time serves as a fact-found human spirituality and the richness of life, which is 'absolute' revelation of his creative talents"'. The absolute in culture reveals itself not as a thing, static reality, some treasure, some sacred repository of values. The cultural value becomes something absolute, on the assumption of a historical

\footnotetext{
${ }^{5}$ Tamże, p. 47.

${ }^{6}$ Tamże, p. 53.

${ }^{7}$ S. Krymskyi, Philosophy as a Way of Humanity and Hope, Kyiv 2000, p. 21.

8 Tamże, p. 22.

${ }^{9}$ Tamże, p. 159.
} 
perspective of unlimited disclosure of its problematic content, in which each era in the invariant culture phenomenon finds all the new meanings ${ }^{10}$.

Archetypes of culture are some spiritual matrixes determining the specific spectrum of standard approaches and solutions of the problems emerging in man's life. In this sense, they are timeless, to be exact - super-temporal, and for all the times, meta-historical, associated with eternity, and therefore they accumulate the past, present and future. Thus, each significant step forward is always associated with relying on past experience and updating the previously unrealized potential.

In terms of its universal humanity, meta-historical and super-temporality determined by the nature of sense-valued Universe, archetypal and structural forms of culture constitute some transcendental invariant foundation of human existence - meta-culture, the subject of meta-history. Meta-history in the interpretation of S. Krymskyi, deals with eternal protoforms, archetypal phenomena (archetypes) in their manifestations (actualization, implementation) in the cultural-historical reality, particularly in the history of world civilization in its diversity of stages, typological, and regionally discrete modifications.

Through developing this position one can conclude that the archetypal forms of meta-history meta-culture must have a hierarchical nature. Multistage line of transitional forms is passed from their universal, transcendental types to a specific socio-cultural manifestation in the life of a society and a particular person. Among them, obviously, one should distinguish: that what is common to all the mankind, phasic and typological (most clearly revealed in the era of civilizations through 'East - West dichotomy), regional-civilizational, and finally, national. Actually, archetypal forms of culture are invariant ones disclosed in the common human dimension. However, in the particular history they manifest themselves through their modification mediated by civilizational, national, class, and other stereotypes.

In this approach, a socio-cultural process is disclosed in the unity of the possible and the actual, logical and random, certain objective logic of events, and the free will of the subjective personality. This is supportive to the ideas of G. Leibniz, which define the world as a game of opportunities and coopportunities in which an individual as a monad disclosed internal potential of "Ego".

10 Tamże, p. 176. 
The analysis of the human history and the modern world in the global and at the same time regional scale (regionalization as the flip side of globalization) in a dynamic state, in the free game of updating and passing opportunities (revealed in a form of indefinite future) is an extremely complicated problem. And S. Krymskyi didn't claim having its all-sided and elaborated solution. However, his methodological approach reveals new horizons of cultural-historical cognition. It turns out that the history is not only a revelation of what is passing, but the assertion of what is remaining. And if one reproduced the history as a picture of everything preserved, it would be quite different from the historical scenarios existing in the academic literature.

The most significant whole for man's life is preserved in the history. For example, the fundamental moral values such as Ten Commandments have been penetrating the civilization process not only formally but also substantively. And everything called the "golden fund" of culture turns out to be the prospect of eternity. This perspective, according to the concept of S. Krymskyi, symbolizes meta-history, that is, the perspective of history in which it appears as saving (not passing) of its formation. Therefore, the movement forward is associated with the transformation of the present from the perspective of missed opportunities of the past, which allows evaluating the history under the signature of meta-history.

Studies of philosophy of culture and social philosophy in the context of modern civilization in the scientific work of S. Krymskyi logically and harmoniously have passed into the research of Ukrainian national culture and spirituality, its identity and existential conditionality, development of the Ukrainian philosophical thought, its cultural and spiritual value. In 1972 by the decree of UNESCO the whole world celebrated the $250^{\text {th }}$ anniversary of the birth of a great son of the Ukrainian people - H. Skovoroda. S. Krymskyi, in cooperation with prominent figures - a philosopher Myroslav Popovych and a poet Ivan Drach, published a substantial work dedicated to the life and work of the thinker. It included new approaches to the understanding of the heritage of $\mathrm{H}$. Skovoroda and its importance for the Ukrainian culture.

The main contribution of S. Krymskyi in the Ukrainian studies was his concept of archetypes of the Ukrainian culture ${ }^{11}$. For S. Krymskyi the major archetypes of the Ukrainian culture are the cordocentrism ('philosophy of the

${ }^{11}$ S. Krymskyi, Archetypes of Ukrainian Culture // Phenomenon of Ukrainian Culture: Methodological Principles of Comprehension, Kyiv 1996; S. Krymskyi, Yu. Pavlenko, Civilization Development of the Mankind, Kyiv 2007; S. Krymskyi, Under Signatureof Sophia, Kyiv 2008. 
heart'), anthropocentrism, sophiology, and states of sensation of parallelism of man and nature, their likeness. He derived them from the Slavic Cultural body known as Eastern Byzantine vaccination of the period of Kyivan Rus. It enabled the rise of Ancient Russ Culture and was existentially experienced, felt and speculated in figurative-symbolic way of life experience in the Cossack era.

The characteristic of the Ukrainian like other Slavic-Orthodox cultures is the dominance of the 'heart' as a metaphor for the intimate depths of the soul. This 'archetype of the heart' is revealed as a 'microcosm', an expression of the inner man, the foundation of humanity (H. Skovoroda), a principle of individuality and organ of perception of God's authority (P. Yurkevych), a path to the ideal and harmony with nature (T. Shevchenko), a source of hope and apprehension (P. Kulish), and a key to the 'economy of the soul', its journey into eternity, sphere of Good and Beauty (N. Gogol).

Anthropocentrism generally typical for Ukrainian national worldview was intensified by the archetype of sophiologic world, regarded as the Book, or the Text of God. In other words, real things were not only interpreted in their natural status, but as symbols, signs of God's Wisdom. The name "Sofia" symbolized the very wisdom of the world created by God, and, in this sense, acted as the starting point for the formation of the concept of sophiologic in the Ukrainian culture. Having been embodied in the ideological and artistic setting of St. Sophia Cathedral in Kyiv, it displayed itself in "Sermon on Law and Grace" written by the Kyivan Metropolitan Hilarion.

Exploring the phenomenon of the Ukrainian culture, S. Krymskyi criticizes limited views on them as the forms of historical existence of individuality and community, as means of the national and cultural identity. He finds mental senses and constants of the spiritual life, moral aspects of the spirit in them. For the philosopher St. Sophia Cathedral is not just a symbol of the wisdom of the world. It is full of the effect of the high heavens that is high aspirations of man's soul. Sophiology is both the meaning and the sanctity of life. Sophiologic basis of cultural topography of Kyiv contains profound sacred meaning and represents a receptacle of the Ukrainian national spirit. Thus, starting with the study of logical-methodological problems of culture in general and the Ukrainian national culture in particular, S. Krymskyi came to the problems of philosophy of spirituality.

Philosophy of spirituality is of key importance in the heritage of the philosopher ("Philosophy as a Way of Humanity and Hope", "Ways and Crossways of Modern Civilization" (1998)). The booklet "Appeals of Spirituality 
of the 21st Century" (2003) based on the lecture for students of Kyiv-Mohyla Academy is noteworthy. On the basis of the achievements of the modern science - cybernetics, synergetics, neurophysiology, noosphere concept, anthropic principle in cosmology and physics - the philosopher reveals the space preconditions of the unity of being and consciousness, puts forward a new concept of human presence in sense-valued Universe. The work raises the question of man's awareness of his path in the Spirit, fate and hope, sketches the contours of spirituality and rational bases of its assertion, analyses semiosis, myth, ethos, art, wisdom as phenomena of spiritual practice, justifies a system of spiritual principles in new contexts.

Among the most important spiritual principles are those which determine the being of the spirit as the basis of an individual: a) monadity of a personality that asserts their uniqueness in the world, ability to represent their era, culture and nation; b) 'third truth' which expresses the irreducibility of life to the alternatives 'happiness - unhappiness', 'success - defeat', etc., breaking the routine for the high horizons of hope; c) existential crescendo which requires to define man's life as a growing climax, and man's death - as a crown of life, not its end; d) non-forcible struggle between good and evil; d) moral mind, which glorifies the mind infused on conscience being able to reject morally flawed ways despite their effectiveness ${ }^{12}$.

In conclusion, it should be noted that S. Krymskyi, using his own terminology was a 'monadic personality', and the meaningful answers that he gave to metaphysical questions, so difficult in the modern era, were based on his own personal experience. His synthesis of scientific-methodological and philosophical-anthropological traditions is a real phenomenon in the philosophical life, an important strategic resource for the moral health of the nation, and human progress of history in the new millennium.

\section{References}

Кримський С. Б., Архетипи украӥнської культури // Феномен украӥнської культури: методологічні засади осмислення, Kуіv 1996, с. 91-112. (Krymskyi S., Archetypes of Ukrainian Culture, Phenomenon of Ukrainian Culture: Methodological Principles of Comprehension, Kyiv 1996).

Кримський С. Б., Закликидуховності XXI століття: [3 циклу щоріч. пам'ят. лекцій ім. А. Оленської-Петришин, 2002 р.] Кyiv 2003 (Krymskyi S., Appeals of Spirituality of XXI Century, Kyiv 2003).

${ }^{12}$ S. Krymskyi, Appeals of Spirituality of the 21st Century, Kyiv 2003, p. 19. 
Кримський С. Б., Під сигнатурою Софії / С. Б. Кримський. - К.: Видавничий дім «Києво-Могилянська академія», 2008 (Krymskyi S., Under Signature of Sophia, Kyiv 2008).

Крымский С. Б., Философия как путь человечности и надежды /С. Б. Крымский, Kyiv 2000 (Krymskyi S., Philosophy as a Way of Humanity and Hope, Kyiv 2000).

Кримський С. Б., Павленко Ю. В., Цивілізаційний розвиток людства, Куіv 2007 (Krymskyi S., Pavlenko Yu., Civilization Development of the Mankind, Kyiv 2007).

Крымский С. Б., Парахонский Б. А., Мейзерский В. М., Эпистемология культуры: Введение в обобщенную теорию познания, Kyiv 1993 (Krymskyi S., Parakhonskyi B., Meizerskyi V., Epistemology of Culture: Introduction to Generalized Theory of Cognition, Kyiv 1993).

Сергей Крымский: наш разговор длиною в жизнь. (Цикл интервью Т. А. Чайки) / С. Б. Крымский, Т. А. Чайка, Куiv 2012 (Sergey Krymskiy: our lifelong conversation, Kyiv 2012).

\footnotetext{
Abstract

The article investigates the evolution of views of a prominent Ukrainian philosopher S. Krymskyi proceeding from logics and methodology of science to philosophy of culture and spirituality.

Key words: Ukrainian philosophy, logics and methodology of science, philosophy of culture, spirituality, S. Krymskyi
} 